\title{
The Influence of Emotional Intelegence, Self-Efficacy, and Altruism on Teacher's Competence in Inclusion Elementary School
}

\author{
Devalia Septiana \\ SD Negeri 02 Bandar Pacitan. Dusun Ngagik RT 01 RW 19 Desa Bandar Kecamatan Bandar \\ Kabupaten Pacitan 63583, Indonesia \\ *Corresponding Author. Email: devalia.septiana@gmail.com \\ Received: 9 June 2017; Revised: 4 September 2018; Accepted: 17 October 2018
}

\begin{abstract}
This study aimed to: (1) describe emotional intelligence, self-efficacy, altruism, and teachers' performance who teach in inclusion elementary schools of Karanganyar Regency, and (2) determine the effect of emotional intelligence, self-efficacy, and altruism on teachers competence who teach in inclusion elementary school of Karanganyar Regency. The research was quantitative research using the ex-post facto method. The results of the study show that: (1) teacher's emotional intelligence is at the medium category, while self-efficacy, altruism, and teachers competence who teach in inclusion elementary school of Karanganyar District are in high category; (2) there is a significant relationship between emotional intelligence with the teacher's competence, with a value of $r=0.560(r>0,244)$, there is a significant relationship between self-efficacy with teacher's competence with a value of $r=0.535$ ( $r>$ 0.244 ), there is a significant relationship between altruism with the teacher's competence, with a value of $r=0.711(r>0.244)$ and there is a significant relationship between emotional intelligence, selfefficacy, and altruism with the teacher's competence, with a value of $F=39.742$ ( $F>2.76)$. Therefore, it concluded that higher emotional intelligence, and altruism the higher the teacher's competence.
\end{abstract}

Keywords: emotional intelligence, self-efficacy, altruism and teacher's competence

How to Cite: Septiana, D. (2018). The influence of emotional intelegence, self-efficacy, and altruism on teacher's competence in inclusion elementary school. Jurnal Prima Edukasia, 6(2), 147-156. doi:https://doi.org/10.21831/jpe.v6i2.14413

Permalink/DOI: https://doi.org/10.21831/jpe.v6i2.14413

\section{Introduction}

United Nations Convention on the Rights of the Child in 1989 confirmed that all children have the right to have education without discrimination in any form. In line with this, UNESCO issued the philosophy of Educational for All. Educational for All implies that education "exists" for all or must accommodate the diversity of students' needs either normal students or students with special needs (An EFA Flagship, 2004). UNESCO then issued an inclusive education policy. This policy is important because, since a long period of time, children with special needs also have a great desire to study in regular schools and also interact with normal children.

In Indonesia, the implementation of inclusive education was marked with the issue of the Circular Letter of the Director General of Primary and Secondary Education on inclusive education that the implementation and development of inclusive education in each district/city have at least four schools consisting of elementary, junior high school, senior high school, and vocational schools. This supported by the regulation of Minister of National Education No. 70 of 2009 concerning inclusive education for students with inclusive and has potential intelligence and/or special talents.

Inclusion education is an educational concept or approach that tries to reach all children. Inclusion education must well implement because all children have the same rights to obtain a quality education and not discriminated. All children have the ability to take lessons without considering any inclusive or disability. Differences are reinforcement in improving learning for all children. Schools and teachers have the ability to learn to respond to different learning needs.

Inclusion education in Karanganyar Regency is protected in the Regent Regulation (Perbup), which is regulation and implementation of inclusion education. The implementation of 
inclusive education has carried out since 2013 and continues to the present. Implementation of inclusive education needs an inclusive school. Based on data from the Karanganyar District Education Office in 2016, there are 29 Elementary Schools of inclusive in Karanganyar Regency spread across 17 districts and have 559 students with special needs. Meanwhile, the school has 29 Special Companion Teacher (GPK) and comes to the elementary school of inclusive only twice a week. A demand of inclusive schools is the competence of teachers in providing education services for all children including children with special needs. In such conditions, the role of classroom teachers who interact with students with special needs every day is very dominant in the development of students with special needs in elementary school of inclusive.

Based on the conditions, then every regular school that organizes inclusive education needs to make adjustments, both from the aspect of school management which is the duty and responsibility of the principal and classroom management and learning which are the duties and responsibilities of the teacher. An important problem in implementing inclusive schools is the role of teachers in teaching children. The teacher has the power to influence the student learning outcomes (Penrose, Perry \& Ball, 2007). Therefore, inclusive schools really need willingness from teachers to achieve good results for student learning process. In addition, teacher attitudes are more positive when teaching older students with special needs than younger children with special needs (Hastings \& Oakford, 2003).

In the study of Ratcliff (2009), stated that teachers thought that teaching the younger children with special should provide a lot of help and need intense interaction, and, in contrast, older children need only a little help. Moreover, Cipkin \& Rizza (2003) stated that teachers who teach at the senior high school (SMA) use a fewer learning strategy compared to teachers who teach in elementary schools (SD) aiming to fulfill the needs of children with special needs. The things make some teachers find it difficulties in teaching children with special needs at the primary education.

Research by Shade \& Stewart (2001) showed that there are a number of teachers who have sufficient self-confidence that they are able to teach students with special needs. In addition, classroom teachers still have difficulty in fulfilling the needs of all students even though they have supported by extraordinary education prog- rams. In general, classroom teacher have poor self-confidence regarding their ability to implement inclusion programs in regular classes as the finding by Gallis \& Tanner (1995).

The initial interview found information that there were a number of teachers who have poor self-confidence on their ability to teach children with special needs, despite, they have trained and followed seminars. The poor of selfconfident within teacher caused by the teacher's duties and responsibilities, besides that, the teacher does not have adequate skills and experience to deal with children with special needs. In such conditions, the teacher needs selfconfidence that they have the ability to teach in inclusive schools. Berry (2006) found that the teacher's confidence on trust and protection in improving student academic performance will make the inclusion class more effective. Teacher self-efficacy is one variable consistently related to positive teaching and student learning outcomes (Penrose, Perry \& Ball, 2007). Gibson \& Dembo, 1984 (Penrose, Perry \& Ball, 2007) found that teachers who have high self-efficacy will be better able to maintain their students' commitment to learning activities.

Self-efficacy of teachers is seen as one supporting factor toward the effective learning and teaching process. Self-efficacy will determine the effort by the teacher, especially when the teacher faces various problems or obstacles in carrying out his duties. A number of studies found that self-efficacy is a variable that may directly influence to teacher's competence. As shown by Bray \& Bates (2013), stated that selfefficacy if used as a "pivot point" in the design of in-service training and professional development activities, teachers can encourage positive beliefs, improve teacher's competence and students' learning outcomes. In line with Harrison, Rainer Jr, Hochwarter, \& Thompson (1997) stated that there is a strong relationship between self-efficacy and performance. Also, Bell and Kozlowski (2002) concluded that the orientation of learning objectives and self-efficacy had a positive relationship with performance.

Bandura distinguished self-efficacy into three dimensions, namely level, generality, and strength (Bandura, Freeman, \& Lightsey, 1999, p.42-50). The dimension of Level is related to the degree of difficulty of the task. Generality dimension refers to the extent to which individuals are confident in their abilities in various task situations, starting from in carrying out an ordinary activity or a certain situation that never carried 
out in a series of tasks or difficult and varied situations. Generality is a feeling of ability shown by individuals in the context of different tasks, among through behavior, cognitive and affective. Strength dimension is a strong belief in one's abilities. This dimension is related to the resilience and tenacity of individuals in fulfilling their duties. Individuals who have strong beliefs and stability towards their ability to do a task will continue to survive in their efforts even though they experience difficulties and challenges.

Chan (2004) in Penrose, Perry \& Ball, 2007) found that "self-efficacy is predicted to be significant with components of emotional intelligence." According to Goleman (2004), emotional intelligence is the ability to recognize one's feelings and other people's feelings, the ability to motivate self and the ability to manage emotions of self and well relationships with others. Until the present, there is no measurement tool to be used to measure a person's emotional intelligence. However, there are several characteristics that indicating someone has emotional intelligence. Goleman (2000, p. 58) details the aspects of emotional intelligence specifically; (1) self-awareness; (2) self-management; (3) motivation; (4) empathy (social awareness); (5) relationship management.

The good emotional intelligence will make the individual may put his emotions in the right portion, sort and manage the mood. Teachers who have high emotional intelligence can manage their emotions well and pay attention to their emotional state and respond properly to their emotions to others. Emotional intelligence plays a significant role in building the competency characteristics of a teacher, considering by the emotional intelligence, a teacher will able to control the emotions and able to play the social role with fellow teachers, students, and the surrounding community.

Previous research conducted on emotional intelligence in the workplace by Boyatzis, Goleman \& Hay (2000). They conducted research on partners of various international consulting institutions. The method was experimental research with a test instrument in the form of an EQ test. The result showed that consultants who have a high EQ score generate more income than those who have a small EQ score. Another study of emotional intelligence also concluded that there is a positive correlation between emotional intelligence and IQ on performance (Ciarrochi, Forgas, \& Mayer, 2000; Abraham, 2004). And the research of Singh \& Jha (2012) stated that there is a relationship between emotional intelligence and performance of teachers who teach in four private universities in Uttar, Pradesh, India.

Likewise with altruism that may build the psychological characteristics of humans, so that they can contribute to the level of commitment and competence of teachers. Altruism is distinguished by feelings of loyalty and obligation (de Waal, 2008). Altruism focuses on motivation to help others and the willingness to conduct good without considering the rewards, meanwhile the duty focus on the moral demands of certain individuals, such as God, kings, special organizations, such as government, or abstract concepts, such as patriotism, and so on. Some people can feel altruism as well as duty, while others don't.

Altruism has a close relationship with feelings of empathy (Sesardic, 1999). An altruistic person has an altruistic motivation and a desire to always help others. The altruistic motivation arises because there are internal reasons within self that lead to positive feelings. So, they can raise actions to help others (Gintis, Bowles, Boyd \& Fehr, 2003). The aspects of altruism refer to Myer (2012, p.205-229) stated that in altruism consists of five things: (1) Empathy; (2) Belief in a just world; (3) Social responsibility (4) Internal locus of control (Internal self-control) (5) Low egocentrism.

Altruism is the concern for the welfare of others without consider to self (Campbell, 2006). Altruism describes a selfless concern for the needs of others. In the world of inclusive education, students may have certain limitations, such as physical, mental, emotional abilities and in an effort to adjust to outside parties or the surrounding environment. In this case, the teacher's duties become more severe with skills and certain skills required both in the field methodology and in the field of therapeutic services. This is not easy and often can affect the competence of teachers who teach in inclusive schools. So, the teacher is also hoping to have an attitude of altruism.

Competent teachers are an indispensable pillar for improving student learning outcomes and the quality of education (Phin, 2014). Aim to improve the quality of teachers; the things need to consider are academic qualifications, competencies, and educator certification (Yazid \& Jabar, 2013). So, good teacher competence will eventually lead to increase on student learning outcome because the pattern of interaction 
between teachers and students plays an important role for the ups and downs of learning outcome achieved by the students. Then, teachers need to know the factors that influence teacher competency, especially internal factors such as emotional intelligence, altruism, and self-efficacy. Those factors are hard to know in plain view. A requirement of professional teachers is a community rather than self-interest orientation. A professional teacher must concern with the community rather than personal motives. Altruism is an idea used to define individuals consciously and sincerely on leading their attention to others and sacrificing; this usually known as prosocial action (Boehm, 1979). The basic criteria for altruism are the desire to help others (Batson, et al., 1991). In a philosophical perspective, the teacher behaves well on his students without regard to rewards; this known as altruism behavior. In this case, altruism indirectly influences the professionalism of a teacher which impacts on the competence of the teacher.

According to the law on Teacher and Lecturer, No. 14 of 2005 article 1 paragraph 10 stated that competence is a set of knowledge, skills, and behaviors that must be owned, internalized, and mastered by the teacher or lecturer in carrying out professional duties. Competence may also interpret as knowledge, skills and basic values which reflected in the habit of thinking and acting. Thus, the competencies possessed by the teacher will show the quality of the teacher.

Broke \& Stone (2005, p.62) stated that teacher competence as "descriptive of qualitative nature of teacher behavior appears to be entirely meaningful." This behavior consists of a combination and knowledge, skills, values and attitudes that reflected in the habit of thinking and acting.

The problem identification in this study was; need to know the effect of self efficacy, emotional intelligence, and altruism on teacher competency. And, the research objectives were to: (1) describe emotional intelligence, selfefficacy, altruism, and teachers' performance who teach in inclusion elementary schools of Karanganyar Regency, and (2) determine the effect of emotional intelligence, self-efficacy, and altruism on teachers competence who teach in inclusion elementary school of Karanganyar Regency.

\section{Method}

The particular research was a quantitative using ex-post-facto method because the symptoms of all the variables have been reasonable in the field. Explanation of the study was correlational causal, which is characterized by the analysis of regression and correlation techniques to determine the causal and functional relationships between independent variables and dependent variables. This ex-post-facto research also tries to find the influence the effect of emotional intelligence, and altruism on the competence of teachers who teach in inclusive schools.

The research conducted in elementary schools that implemented an inclusion program in the area of Karanganyar Regency. The research conducted from November 2015 to March 2017.

The population was all teachers who teach in inclusive schools in Karanganyar Regency. Inclusion schools based on data from the Education and Culture Office of Karanganyar regency in 2013, there were 29 schools and 185 classroom teachers.

The population consisted of 15 districts with different proportions numbers of elementary school inclusion and research subjects. The cluster of this study divided into elementary school inclusion in districts which close to the city/district center and inclusive elementary schools located in districts which are far from the city/district center.

The sampling selection technique was multistage cluster sampling. Multistage cluster sampling is a sampling selection process that performs through two or more sampling stages (Cochran, 1977, p.314). The multistage cluster sampling method has an expansion in the sampling process, i.e indirect sampling selection on the element, but firstly through the cluster.

Slovin formula used to find out the number of subjects (Umar, 2008, p. 78). Based on the calculations using the Slovin formula, 65 research subjects were the sample members. The research subjects were selected from 10 inclusion elementary schools in Karanganyar Regency. Of the 10 inclusion elementary schools, 6 elementary school inclusions located far from the city/district center which consisted of 41 research subjects and 4 inclusion elementary schools located close to the city/district center which consisted of 24 research subjects.

The particular research used psychological scale in the data collecting technique. The preparation of a psychological scale carried out in several stages (Azwar, 2005, p. 12), namely: (1) Identification of measuring objectives through the determination of psychological constructs; 
(2) Operationalization of concepts through behavioral indicators; (3) Selection the stimulus and scaling format; (4) Writing items; (5) Review the items by the author and expert; (6) Trial; (7) Analysis of items; and (8) Selection the items through test of reliability and validity.

Instruments arranged based on the instruction in general. The instrument instruction was about the instrument of emotional intelligence taken from the theory of emotional intelligence aspects by Goleman (2000); the selfefficacy scale adopted from the self-efficacy instrument by Bandura; the altruism scale taken from the aspects of the altruism Myer (2012) and the teacher competency scale based on four domains of teacher competency. Based on the instruction, arranged an emotional intelligence scale $=35$ items, the instruments of self-efficacy $=28$ items and instruments of altruism $=35$ items. The scale arranged and filled out by the teacher who was the subject of the study. And, 30 items of the teacher competency scale instrument filled out by the principal.

Data Analysis Technique

\section{Instrument Validity and Reliability}

The validity conducted through expert judgment by two experts in the field in line with this study. The recapitulation of the calculation results of validity is presented in Table 1 .

Table 1. The recapitulation of the calculation results of Expert Judgement validity

\begin{tabular}{lc}
\hline \multicolumn{1}{c}{ Instrument } & $\begin{array}{c}\text { Result of } \\
\text { validity test }\end{array}$ \\
\hline Scale of Emotional Intelligence & 0,714 \\
Scale of Self Efficacy & 0,928 \\
Scale of Altruism & 0,8 \\
Scale of Teacher Competency & 0,8 \\
\hline
\end{tabular}

The trial subjects consisted of 30 teachers on the inclusive elementary school from 5 inclusion elementary schools in Karanganyar Regency, spread across 5 different districts. The results of the instrument on trial data after analyzed using product moment with the help of SPSS showed that: (1) from the 35 questions on scale of emotional intelligence, 28 items were valid and 7 items were invalid; (2) from the 28 questions on self efficacy scale, 25 items were valid and 3 items were invalid; (3) from the 35 items on altruism scale, 26 items were valid and 9 items were invalid; and (4) from the 30 items on teacher competency scale, 26 items were valid and 4 items were invalid.
The reliability results obtained after the trial showed that each instrument was reliable and presented in Table 2.

Table 2. Estimated of Reliability of Research Instruments

\begin{tabular}{ll}
\hline Scale & Estimated Reliability \\
\hline Emotional Intelligence & $\mathrm{r}=0,876$ \\
Self Efficacy & $\mathrm{r}=0,847$ \\
Altruism & $\mathrm{r}=0,865$ \\
Teacher Competence & $\mathrm{r}=0,834$ \\
\hline
\end{tabular}

Aiming to determine the data processing using parametric statistical calculations previously performed classical assumption test or prerequisite test. The classical assumption test must perform to test the feasibility of the regression analysis model. The classical assumption tests were: (1) Normality test; (2) Homogeneity Test; (3) Linearity test; (4) Multicollinearity test; (5) Heteroscedasticity Test; (6) Autocoleration Test;

The results of the classical assumption test showed that the research data were feasible to be analyzed using regression analysis.

\section{Results and Discussion}

Results

\section{The Result of the First Hypothesis Test}

Based on the analysis with the help of the SPSS program, the probability or significance value showed that the effect of emotional intelligence $\left(\mathrm{X}_{1}\right)$ on teacher competence $(\mathrm{Y})$, the significance value $0.00<0.05$ and $r_{\mathrm{xy}}(0.560)>r_{\text {table }}(0.244)$, Ha accepted and Ho rejected. So, there is positive and significant influence emotional intelligence on the competence of teachers who teach in inclusive schools in Karanganyar Regency.

Table 3. The Result of the First Hypothesis Test

\begin{tabular}{lllll}
\hline Correlation & $\mathbf{r}_{\mathbf{x y}}$ & $\mathbf{r}_{\text {table }}$ & Significance & Des. \\
\hline $\mathrm{X}_{1}->\mathrm{Y}$ & 0,560 & 0,244 & 0,00 & Significance \\
\hline
\end{tabular}

\section{The Result of the Second Hypothesis Test}

Based on the analysis with the help of the SPSS program, the probability or significance value showed that the effect of Self Efficacy $\left(\mathrm{X}_{2}\right)$ on teacher competency $(\mathrm{Y})$, the significance value $0.00<0.05$ and $r_{x y}(0.535)>r_{\text {table }}(0.244)$, then $\mathrm{Ha}$ accepted and Ho rejected. So, there is a positive and significant influence Self Efficacy on the competence of teachers who teach in inclusive schools in Karanganyar Regency. 
Table 4. The Result of the Second Hypothesis Test

\begin{tabular}{ccccl}
\hline Correlation & $\mathbf{r}_{\mathbf{x y}}$ & rtable & Significance & Des. \\
\hline $\mathrm{X}_{2}->\mathrm{Y}$ & 0,535 & 0,244 & 0,00 & Significance \\
\hline
\end{tabular}

The Result of the Third Hypothesis Test

Based on the analysis with the help of the SPSS program, the probability or significance value showed that the effect of altruism $\left(\mathrm{X}_{3}\right)$ on teacher competence $(\mathrm{Y})$, the significance value $0.00<0.05$ and $\mathrm{r}_{\mathrm{xy}}(0.711)>\mathrm{r}_{\text {table }}(0.244), \mathrm{Ha}$ accepted and Ho rejected. So, there is positive and significant influence altruism on the competence of teachers who teach in inclusive schools in Karanganyar Regency.

Table 5. The Result of the Third Hypothesis Test

\begin{tabular}{lllll}
\hline Correlation & $\mathrm{r}_{\mathrm{xy}}$ & $\mathrm{r}_{\text {table }}$ & Significance & Des. \\
\hline $\mathrm{X}_{3}->\mathrm{Y}$ & 0,711 & 0,244 & 0,00 & Significance \\
\hline
\end{tabular}

The Result of the Fourth Hypothesis Test

Based on Table 6, obtained $\mathrm{F}_{\text {count }}$ value of $39.742>2.76 \mathrm{~F}_{\text {table }}$ and significance $0.00<0.05$. So, Ha accepted and Ho rejected. Means, there is a positive and significant influence among emotional intelligence, and altruism on the competencies of teachers who teach in inclusive schools in Karanganyar Regency.

Table 6. The Result of the Fourth Hypothesis Test

\begin{tabular}{ccccc}
\hline Fregression & F table Sig & $\begin{array}{c}\text { Regression } \\
\text { Equation }\end{array}$ & Contribution \\
\hline \multirow{3}{3}{39,742} & 2,76 & 0,00 & $\begin{array}{l}\text { Y=- } \\
70,219+0,482 \mathrm{X}_{1}+\end{array}$ & $64,5 \%$ \\
& & & $0,031 \mathrm{X}_{2}+0,683 \mathrm{X}_{3}$ & \\
\hline
\end{tabular}

The regression equation was $\mathrm{Y}=$ $70,219+0,482 X_{1}+0,031 X_{2}+0,683 X_{3}$. Means, if $\mathrm{X}_{1}, \mathrm{X}_{2}$ and $\mathrm{X}_{3}$ were 0 , then $\mathrm{Y}$ variable was 70,219 . If $X_{1}$ increases one, then $Y$ increases into 0.482 with $\mathrm{X}_{2}$ and $\mathrm{X}_{3}$ were constant. If $\mathrm{X}_{2}$ increases one, then $\mathrm{Y}$ increases into 0.031 with $X_{1}$ and $X_{3}$ were constant. If $X_{3}$ increases one, then $\mathrm{Y}$ increases into 0.683 with $\mathrm{X}_{1}$ and $\mathrm{X}_{2}$ were constant, and so on.

The correlation coefficient between $\mathrm{Y}$ criteria and the three predictors $\left(\mathrm{X}_{1}, \mathrm{X}_{2}\right.$, and $\left.\mathrm{X}_{3}\right)$ was 0.831 . This showed a strong influence. Whereas, the significance of multiple correlation coefficients calculated using $F$ value. Based on multiple correlation analysis, it obtained $F_{\text {count }}$ of 39,742 , and then consulted with $F_{\text {table }} 2.76$. And, find out that the value of $F_{\text {count }}$ was 39.742> 2.76 $\mathrm{F}_{\text {table. Means, the double correlation was }}$ significant.
The coefficient of determination (R2) in the multiple regression analysis of three predictors was 0.645 . Means, there was an influence of $64.5 \%$ with teacher competence and $35.5 \%$ influenced by unexamined factors.

Based on the results, there are some interesting things need to have further re-check. The results of the hypothesis test indicated that there is a positive and significant influence among emotional intelligence, self-efficacy, and altruism on teacher competencies collectively, as well as individually. Means, all hypotheses, among the first, second, third and fourth hypotheses presented in this study were acceptable.

\section{Discussion}

The Effect of Emotional Intelligence on the Competence of Teachers Who Teach in Inclusive Schools in Karanganyar Regency.

Emotional intelligence needs to overcome problems in life and become an important basis for being a human who is full of responsibility, attentive, productive and optimistic in dealing with and solve the problems (Patton, 2001, p.1). Furthermore, Bar-On (Cooper, Sawaf, \& Widodo, 1998, p.73) stated that emotional intelligence is an ability that should be possessed by each individual to adapt to his work. Emotional intelligence skills are skills that may be taught and improved through education (Mayer, Salovey, \& Caruso 2000; Shapiro, 2003).

Teachers do not only use skills and abilities in carrying out their duties with intellectual abilities acquired in teacher and training education, but also use emotional abilities possessed by the teacher. The ability to control emotions, mutual respect and the ability to perceive emotions of others are the form of emotional intelligence. Emotional intelligence is hoping to help teachers carry out tasks and roles in line with established standards (Mulyasa, 2007, p.161162).

Based on the statement and supported with the research result, showed that there is a significant effect of emotional intelligence on teacher competence. This conclusion based on the Pearson correlation test with a significant value of $0.00<0.05$ and $r_{x y}(0.560)>r_{\text {table }}(0.254)$. Then, $\mathrm{H}_{\mathrm{o}}$ rejected and $\mathrm{H}_{\mathrm{a}}$ accepted.

Viewed from the theory and results, indicated that emotional intelligence has an effect on teacher competence. The results may provide references for teachers, especially inclusive elementary school teachers that high emotional 
intelligence influences to competence of teachers. So, inclusive elementary school teachers hopefully can optimize the learning activities which are main responsibilities of teachers.

The Effect of Self-Efficacy on the Competence of Teachers Who Teach in Inclusive Schools in Karanganyar Regency.

According to its definition, self-efficacy is self-skill which is basically the level of selfeffectiveness in facing the life. The ability is also deal with and deal with situations and challenges. Self-skill influences our choice of activities that we meet in life.

The definition of self-efficacy is a term created by Albert Bandura on social learning theory. Self-efficacy relates to one's self-confidence in achieving what they want to achieve. Have self-confidence, means it's not wasting the time of whole life because expect a different, dreaming and hopeful life.

From the notion of self-efficacy, there is a possibility that self-efficacy may affect the competence of a teacher, because the factors that affect on teacher competence are not only from external the teacher's self but also from within (internal) the teacher. The low competence of teachers is caused by several factors, which are an external and internal factor. As an important factor, teachers are required to have basic competencies and abilities, such as self-efficacy including self-proficiency, self-ability, and selfconfidence to increase the competency of the teacher.

Based on the statement and completed with the research results, showed that there is a significant effect of self-efficacy on teacher competence. This result is shown based on the Pearson correlation test with a significant value of $0.00<0.05$ and $r_{x y}(0.535)>r_{\text {table }}(0.244)$. Then, $\mathrm{H}_{\mathrm{o}}$ rejected and $\mathrm{H}_{\mathrm{a}}$ accepted. The results support the research by Mcdougall \& Kang (2000), Luszczynska, Gutiérrez-Doña, \& Schwarzer (2005), and Cherian \& Jacob (2013) stated that self-efficacy has a positive effect on teacher competence.

The high self-efficacy, when possessed by teachers, may affect learning and student success. Teachers with high self-efficacy tend to be open to new ideas, have a great desire to try new methods to meet their students' needs, and perform better teaching (Gibson \& Dempo, 1984 in Bandura, 1993; Bandura, 1994). Teachers with high self-efficacy will able to motivate the students and improve cognitive development.
Based on theory and research results, found out that self-efficacy has an influence on mutual teacher competencies. With the results, it may provide references for teachers, especially inclusive elementary school teachers with high self-efficacy, then teacher competencies will also increase which ultimately improve self-quality, improving the quality of students, knowing difficulties in teaching, determining learning methods and selecting media in learning. And, it is expected that teachers on the inclusive elementary school can optimize the students' learning activities which are main responsibilities as teachers.

\section{The Effect of Altruism on the Competence of Teachers Who Teach in Inclusive Schools in Karanganyar Regency.}

Altruism is a human nature that is willing to do something for other without hoping to get any reward. In contrast, egoism prioritizes its own interests over the interests of others to pursue pleasure (Sears, Freedman, Peplau, \& Adryanto, 1994). Altruism based on a considerable empathy towards others. Someone with altruism tends to be more willing to care and pay attention to other people who need help.

Teachers with high altruism will be willing and sincere in providing services to students in the learning activities. So, it will give positive results to increase teacher competency.

Based on the statement and completed with the research results, it showed that there is a significant influence on teacher's altruism on teacher competency. This result based on the Pearson correlation test with a significant value of $0.00<0.05$ and $r_{x y}(0.711)>r_{\text {table }}(0.244)$. Then, $\mathrm{H}_{\mathrm{o}}$ rejected and $\mathrm{H}_{\mathrm{a}}$ accepted.

Based on theory and research results, found out that self-efficacy has an influence on mutual teacher competencies. With the results, it may provide references for teachers, especially inclusive elementary school teachers with high self-efficacy, then teacher competencies will also increase which ultimately improve self-quality, improving the quality of students, knowing difficulties in teaching, determining learning methods and selecting media in learning. And, it is expected that teachers on the inclusive elementary school can optimize the students' learning activities which are main responsibilities as teachers. 
Jurnal Prima Edukasia, 6 (2), July 2018 -154

Devalia Septiana

The Effect of Emotional Intelligence, and Altruism on the Competence of Teachers Who Teach in Inclusive Schools in Karanganyar Regency.

Teachers have more complex duties and functions, so they need to have good knowledge competencies and personal competencies that include knowledge, skills, attitudes, and values. In this study, it discussed the issue of is there a significant influence among the factors of emotional intelligence, self-efficacy, and altruism on the teachers' competence in inclusive elementary school in Karanganyar Regency. The finding proved that emotional intelligence, self-efficacy, and altruism that are positive and significant will produce good synergies for teacher competence.

Based on findings, showed that the influence was strong as indicated by the contribution value of variables of emotional intelligence, self-efficacy, and altruism on teacher competency was $64.5 \%$ (adjusted $\mathrm{R}^{2}$ ), and $35.5 \%$ was another variable that may influence on the competency of teachers.

Based on multiple regression tests, obtained values on influences that $F_{\text {count }}$ was 39.742> $2.76 \mathrm{~F}_{\text {table }}$ and significance of $0.00<0.05$. So, $\mathrm{H}_{\mathrm{a}}$ accepted and $\mathrm{H}_{0}$ rejected. Means, the three independent variables (emotional intelligence, and altruism) have a significant influence on teacher competence.

Further analysis of the influences showed some facts; (1) each increase or decrease in one unit of emotional intelligence variable $\left(\mathrm{X}_{1}\right)$, it followed by an increase or decrease of 0.482 in the teacher competency variable (Y); (2) each increase and decrease in one unit of self-efficacy variable $\left(\mathrm{X}_{2}\right)$, it followed by an increase or decrease of 0.031 in the teacher competency variable (Y); and (3) each increase or decrease in one unit of altruism variable $\left(\mathrm{X}_{3}\right)$, it followed by an increase or decrease of 0.683 in the teacher competency variable $(\mathrm{Y})$.

In short, it concluded that the higher among emotional intelligence, self-efficacy, and altruism, the better the teacher's competency. In other words, it may state that the increased emotional intelligence, self-efficacy and altruism variables together in a positive direction, then it may predict contributing positively to the teachers' competence on the inclusive elementary school in Karanganyar Regency.

\section{Conclusion}

Based on data analysis, it concluded that the results of data description on the four variables have differences from each other. In the variable of emotional intelligence, the teachers of elementary school inclusion in Karanganyar regency concluded in the medium category. In the variable of self-efficacy, teachers' altruism and teacher competence concluded in the high category.

In line with the purpose of this study, it aimed to determine the influence of emotional intelligence, self-efficacy, and altruism on the teachers' competence on the inclusive elementary school in Karanganyar Regency. The findings showed that the factors of emotional intelligence, self-efficacy, and altruism have a positive and significant influence on teacher competence. The findings showed that teacher competence will increase proportionally when there is an increase in emotional intelligence, self-efficacy, and altruism.

\section{References}

Abraham, R. (2004). Emotional competence as antecedent to performance: A contingency framework. Genetic, Social, and General Psychology Monographs, 130 (2), 117143

An EFA Flagship. (2004). The rights to education for persons with disabilities: Towards inclusion, (Online), http://unesdoc.unesco.org/education_for_ all_(efa_america)_inclusion.pdf. Diunduh 01 Desember 2014

Azwar, S. (2005). Penyusunan skala psikologi. Yogyakarta: Pustaka Pelajar.

Bandura, A. (1993). Perceived self-efficacy in cognitive development and functioning. Educational psychologist, 28(2), 117-148.

Bandura, A. (1994). "Self efficacy” In V.S. Ramachaudran (Ed). Encyclopedia of Human Behaviour, 4, 71-81. New York: Academic Press.

Bandura, A., Freeman, W. H., \& Lightsey, R. (1999). Self-efficacy: The exercise of control. New York, NY.: Freeman

Batson, C. D., Batson, J. G., Slingsby, J. K., Harrell, K. L., Peekna, H. M., \& Todd, R. M. (1991). Empathic joy and the empathyaltruism hypothesis. Journal of Personality and Social Psychology, 61(3), 413-426. 
Boyatzis, R. E., Goleman, D., \& Rhee, K. (2000). Clustering competence in emotional intelligence: Insights from the Emotional Competence Inventory (ECI). Handbook of emotional intelligence, 99(6), 343-362.

Berry, R. A. W. (2006). Inclusion, power, and community: Teachers and students interpret the language of community in an inclusion classroom. American Educational Research Journal, 43(3), 489529.

Bell, B. S., \& Kozlowski, W. J. (2002). Goal orientation and ability: Interactive effects on self-efficacy, performance, and knowledge. Journal of Applied Psychology, 87(3), 497-505.

Boehm, C. (1979). Some problems with altruism in the search for moral universals. Behavioral Science, 24(1), 15-24.

Broke, L., \& Stone, D. (2005). Competency based on training. New York: McGrawHill Company.

Campbell, R. L. (2006). Reply to Robert H. Bass," egoism versus rights"(spring 2006): altruism in Auguste Comte and Ayn Rand. The Journal of Ayn Rand Studies, 357-369.

Ciarrochi, J., Forgas, J. P., \& Mayer, J. D. (Eds.). (2001). Emotional intelligence in everyday life: A scientific inquiry. Psychology Press.

Cherian, J., \& Jacob, J. (2013). Impact of self efficacy on motivation and performance of employees. International Journal of Business and Management, 8(14), 80.

Cipkin, G \& Rizza, F. (2003). The attitude of teachers on inclusion. Retrived from http://www.nummarius.com/The_Attitude _of_Teachers_on_Inclusion.pdf.

Cochran, W. G. (2007). Sampling techniques. John Wiley \& Sons.

Cooper, R. K., Sawaf, A., \& Widodo, A. T. K. (1998). Executive EQ: kecerdesan emosional dalam kepemimpinan dan organisasi. Gramedia Pustaka Utama.

Departemen Pendidikan Nasional. (2005). Undang-Undang No.14 Tahun 2005 tentang guru dan dosen.

De Waal F.B.M. (2008). Putting the altruism back into altruism: The evolution of empathy. Annual Review of Psychology, 59, 279-300.
De Waal, F. B. (2008). Putting the altruism back into altruism: the evolution of empathy. Annu. Rev. Psychol., 59, 279-300.

Florida State University Center for Prevention and Early Intervention Policy. (2002). What is inclusion?. Retrived from http://www.pdfgeni.com/ref/what-isinclusion-pdf.html.

Galis, S.A., \& Tanner, C.K. (1995). Inclusion in elementary schools: A survey and policy analysis.Education Policy Analysis Archives, 3 (15).

Gintis, H., Bowles, S., Boyd, R., \& Fehr, E. (2003). Explaining altruistic behavior in humans. Evolution and Human Behavior, 24(3), 153-172.

Goleman, D. (2000). Working with emotional intelligence: Kecerdasan emosi untuk mencapai puncak prestasi (cetakan ketiga).Terjemahan: Alex Tri K.W. Jakarta: Gramedia Pustaka Utama.

Goleman, D. (2004). Emotional intelligence. Terjemahan: T. Hermaya. Jakarta: PT Gramedia Pustaka Utama.

Harrison, A. W., Rainer Jr, R. K., Hochwarter, W. A., \& Thompson, K. R. (1997). Testing the self-efficacy-performance linkage of social-cognitive theory. The Journal of Social Psychology, 137(1), 79-87.

Hastings, R. P., \& Oakford, S. (2003). Student teachers' attitudes towards the inclusion of children with special needs. Educational psychology, 23(1), 87-94.

Singh, I., \& Jha, A. (2012). Teacher effectiveness in relation to emotional intelligence among medical and engineering faculty members. Europe's Journal of Psychology, 8(4), 667-685.

Luszczynska, A., Gutiérrez-Doña, B., \& Schwarzer, R. (2005). General selfefficacy in various domains of human functioning: Evidence from five countries. International Journal of Psychology, 40(2), 80-89.

Mayer, J.D., Salovey, P., \& Caruso, D.R.(2000). Models of emotional intelligence. In $\mathrm{J}$. Sternberg (Ed.), Handbook of intelligence (pp. 396-420). New York: Cambridge University Press.

Mcdougall \& Kang. (2008). Memory selfefficacy and memory performance in older males. The University of Texas at Austin. 
Yazid, M., \& Jabar, C. (2013). Hubungan mutu guru, kepemimpinan kepala sekolah, dan status ekonomi guru dengan kinerja guru SD Kecamatan Suralaga Lombok Timur. Jurnal Prima Edukasia, 1(1), 94-102. doi:http://dx.doi.org/10.21831/jpe.v1i1.23 26

Mulyasa, E. (2007). Menjadi guru profesional: Menciptakan pembelajaran kreaktif dan menyenangkan, Bandung: Remaja Rosdakarya.

Myer, D, G. (2012). Psikologi sosial. Terjemahan: Aliya Tusyani dkk. Jakarta: Salemba Humanika.

Nikki, B \& Reid, B. (2013). Self efficacy belief and teacher effectiveness: Implications for professional development. Journal The Professional Educator, Vol.XXVI (1).

Patton, H. (2001). Emotional intelligence di tempat kerja. Terjemahan: Zaini Dahlan. Jakarta:Pustaka Delaprasa.

Penrose, A., Perry, C., \& Ball, I. (2007). Emotional intelligence and teacher self efficacy: The contribution of teacher status and length of experience.Journal of Educational Psychology, Vol 17 (1), 100125.

Phin, C. (2014). Teacher competence and teacher quality in cambodia's educational context linked to in-service teacher training: An examination based on a questionnaire survey. International Journal of Educational Administration and Policy Studies, 6(4), 62-69.

Presiden Republik Indonesia. (2005). Peraturan Pemerintah RI Nomor 19, Tahun 2005, tentang standar nasional pendidikan.
Ratcliff, O.Y.M. (2009). Voices of classroomsmanagers: Their realities of full inclusion. Electronic Journal for Inclusive Education, Vol. 2(4).

Republik Indonesia. (2003). Undang-Undang RI Nomor 20, Tahun 2003, tentang Sistem Pendidikan Nasional.

Sears, D. O., Freedman, J. L., Peplau, L. A., \& Adryanto, M. (1994). Psikologi sosial. Jakarta: Erlangga.

Sesardic, N. (1999). Altruism. Brit J. Phil. Sci., $50,457-466$.

Shade, R. A., \& Stewart, R. (2001). General education and special education preservice teachers' attitudes toward inclusion. Professional Development Collection, Vol.46 (1), 264-273.

Shade, R. A., \& Stewart, R. (2001) General Education and Special Education Preservice Teachers' Attitudes Toward Inclusion. Preventing School Failure: Alternative Education for Children and Youth, 46(1), 37-41, DOI: $10.1080 / 10459880109603342$

Shapiro, L. E. (2003). Mengajarkan emotional intelligence pada anak. Jakarta: PT Gramedia Pustaka Utama.

Umar, H. (2008). Metode penelitian untuk skripsi dan tesis bisnis. Jakarta: PT RajaGrafindo Persada.

UNESCO. (1994). Penyataan salamanca dan kerangka aksi mengenai pendidikan kebutuhan khusus, (Online),http://www.idpeurope.org/indonesia/docs/SALAMANC A_indo.pdf, diunduh 02 Desember 2014. 